\title{
IMPLEMENTASI PERATURAN PRESIDEN NOMOR 112 TAHUN 2007 TENTANG PENATAAN PASAR TRADISIONAL DI KECAMATAN SOMBA OPU KABUPATEN GOWA
}

\author{
Abd. Azis', Juliati Saleh², Muhammad Tahir ${ }^{3}$ \\ 1)Jurusan Ilmu Administrasi Negara Fisipol Unismuh Makassar \\ 2) Jurusan Ilmu Administrasi Negara Fisipol Unismuh Makassar \\ 3) Jurusan Ilmu Administrasi Negara Fisipol Unismuh Makassar
}

\begin{abstract}
ABSTRACK
This research aimed to determine the implementation of the presidential decree number 112 of 2007 regarding the arrangement of the traditional markets in Somba Opu District, Gowa Regency. The type of research was descriptive qualitative research with phenomenological research type. Data was collected through interviews, observation and documentation. It could be seen from the three indicators of the location of traditional markets refers to urban land, and detail of Urban Land use Plan, including zoning location regulation, the establishment of strategic trading center traditional market with the same market segment should not be too close together, Establishment traditional markets was done by revitalizing physical infrastructure, urban land, social, cultural and local communities, procurement of parking areas was not optimally yet and it would give effect in difficulties for the procurement of parking facilities.
\end{abstract}

Keywords : governance, market, traditional

\begin{abstract}
ABSTRAK
Penelitian ini bertujuan untuk mengetahui implementasi peraturan presiden nomor 112 tahun 2007 tentang penataan pasar tradisional di Kecamatan Somba Opu Kabupaten Gowa. Jenis penelitian yang digunakan adalah penelitian deskriptif kualitatif dengan tipe penelitian fenomenologi. Data dikumpul melalui wawancara, observasi, dan dokumentasi. Ini dapat dilihat dari tiga indikator yaitu lokasi pasar tradisonal mengacu tata ruang wilayah/Kota, dan rencana detail Tata Ruang Kabupaten/Kota, termasuk peraturan zonasinya lokasi pendirian pasar tradisional yang strategis pusat perdagangan dengan segmen pasar yang sama tidak boleh terlalu berdekatan, Pendirian pasar tradisional dilakukan dengan melakukan revitalisasi sarana dan prasarana fisik, tata ruang wilayah, budaya maupun sosial masyarakat setempat, penyediaan Area Parkir belum optimalnya penyediaan areal parkir dan akan berakibat kesulitan untuk pengadaan fasilitas parkir.
\end{abstract}

Kata Kunci : Penataan, pasar, Tradisional 


\section{PENDAHULUAN}

Seiring

dengan

perkembangan zaman, bangsa

Indonesia telah dihadapkan kepada tantangan persaingan dalam perekonomian yang ditandai dengan adanya perdagangan bebas yang sudah masuk kedalam sistem perekonomian Indonesia. Hal ini secara langsung telah mengakibatkan munculnya persaingan dalam hal perdagangan pada berbagai ranah dan prosesnya dari waktu ke waktu terutama dalam pentaan pasar tradisional. Inti dari fenomena tersebut adalah munculnya semangat kompetisi diantara para pelaku ekonomi dan pasar di dalam kaitannya dengan pengembangan usaha mereka. Sementara itu persaingan harus bisa mengetahui apa yang seharusnya diperbaiki di dalam meningkatkan perekonomiannya. Dalam hal demikian pihak pemerintah harus bisa memberikan fasilitas kepada publik untuk mempermudah jalannya perekonomian dan aktifitas usaha mereka.
Pasar tradisional merupakan pasar yang menjadi penyumbang pertumbuhan ekonomi di Indonesia, Kabupaten Gowa mempunyai pasar tradisional yang berada dibawah PD Pasar di masing-masing daerah Kabupaten.

Peraturan Daerah Kabupaten Gowa Nomor 5 Tahun 2009 tentang penataan dan pembinaan pedagang kaki lima dinyatakan bahwa penyelenggaraan penataan dan pembinaan pedagang kaki lima yang bertujuan untuk mewujudkan usaha yang aman, nyaman, produktif dan berkelanjutan, yang kemudian dipertegas dalam pasal 7 ayat 1 bahwa setiap pedagang kaki lima wajib bertanggung jawab terhadap ketertiban, kebersihan, keindahan, kesehatan lingkungan dan keamanan disekitar tempat pasar atau usaha.

Penataan pasar di Kecamatan Somba Opu Kabupaten Gowa dimana ada 2 (dua) pasar tradisional yang berada dikecamatan somba opu yang meliputi pasar sentral sungguminasa dan pasar induk mamminasata sangat memerlukan waktu yang lama serta bertahap, terlebih lagi Pasar Tradisional di 
Kecamatan Somba Opu merupakan pasar tradisional yang keberadaanya sudah lama dan merupakan salah satu pasar terlama di Kecamatan Somba Opu. adanya sampah yang tertumpuk, penataan pedagang yang kurang, penataan ulang dalam mewujudkan pasar tradisional yang berbasis modern sesuai dengan kebijakan dari Pemerintah Kabupaten Gowa tentang penataan dan pembinaan pasar tradisional, pusat perbelanjaan dan toko modern. Dengan adanya kebijakan tersebut bisa dijadikan acuan untuk menjadikan Pasar Tradisional di Kecamatan Somba Opu sebagai pasar tradisional modern. Modern sudah terbilang berhasil dikarenakan adanya formasi penataan kios, los serta pedagang yang sesuai dengan kelompok-kelompok pedagang, untuk merealisasikan pasar tradisional yang berbasis modern harus adanya koordinasi dari daerah pusat terkait anggaran yang diperlukan, perencanaan jangka waktu dalam penataan pasar serta kerjasama dari PD Pasar, kenyataan dilapangan bahwa peraturan hanya teori yang belum dapat diterapkan sampai saat ini. Keterhambatan penerapan tersebut dikarenakan keputusan penerapan kebijakan yang lama, seperti diketahui pasar tradisional adalah pasar yang dikelola dengan sistem kelembagaan yang desentralisasi yaitu penataan dan pengelolaan pasar harus menunggu keputusan dari pusat.

Pada sisi lain faktor penghambat penataan ke arah harapan tersebut terhambat yang justru hambatan itu muncul dan secara asumtif berasal dari sisi kelembagaan birokrasi yang dalam konteks proses implementasi tentang penataan nampaknya tidak berjalan atau malahan belum terkonstruk secara lebih kohesif dan konprehensif seperti faktor komunikasi, sumber daya manusi dan sarana dan prasarana. Sehingga hingga saat ini pasar tradisional memiliki sejumlah kelemahan yang membuatnya kurang kompetitif dibandingkan dengan pasar modern atau perusahaan skala besar dan memiliki investasi cukup besar Secara ekonomis, dalam berbagai analisis diketengahkan bahwa pengembangan pasar tradisional 
wajib dilakukan untuk meningkatkan daya jual. Ada dua langkah yang lazim dilakukan untuk mengembangkan.Pasar, yaitu renovasi dan revitalisasi. Renovasi adalah kegiatan yang berkaitan dengan perbaikan kualitas fisik bangunan, sedangkan revitalisasi adalah pengkonsepan ulang sistem bangunan, baik dari sisi internal maupun eksternal. Fokus utama revitalisasi adalah pada pengkonsepan ulang sistem bangunan. Selain internal pasar, revitalisasi dilakukan untuk memadukan pasar dengan lingkup eksternalnya. (Djatmiko, 2011:23) Toko modern adalah toko dengan sistem pelayanan mandiri, menjual berbagai jenis barang secara eceran yang berbentuk minimarket, supermarket,departement store, hypermarket ataupun grosir yang berbentuk perkulakan.

(Wahab, 2004:65) Secara lebih luas, implementasi dapat didefinisikan sebagai proses administrasi dari hukum (statuta) yang didalamnya tercakup keterlibatan berbagai macam actor, organisasi, prosedur, dan tekhnik yang dilakukan agar kebijakan yang telah ditetapkan mempunyai akibat, yaitu tercapainya tujuan kebijakan.

$$
\text { Kusumanegara (2010:97). }
$$

Implementasi kebijakan pada prinsipnya adalah cara agar sebuah kebijakan dapat mencapai tujuannya. Tidak lebih dan tidak kurang. Untuk mengimplementasikan. Djatmiko. (2011) kebijakan publik, ada dua pilihan langkah yang ada, yaitu langsung mengimplementasikan dalam bentuk program atau melalui formulasi kebijakan derivat atau turunan dari kebijakan publik tersebut. Rangkaian implementasi kebijakan dapat diamati dengan jelas yaitu dimulai dari program, ke proyek dan ke kegiatan. Model tersebut mengadaptasi mekanisme yang lazim dalam manajemen, khususnya manajemen sektor publik. Kebijakan diturunkan berupa program program yang kemudian diturunkan menjadi proyek-proyek, dan akhirnya berwujud pada kegiatan-kegiatan, baik yang dilakukan oleh pemerintah, masyarakat maupun 
kerjasama pemerintah dengan masyarakat.

$$
\text { Pendapat senada juga }
$$
dikemukakan oleh Mankiw, yang menyatakan bahwa pasar adalah sekelompok pembeli dan penjual dari suatu barang atau jasa (Mankiw N. Gregory, 2006:78). Ada empat faktor kriteria penting dalam implementasi, menurut teori George C. Edward Edward III dalam Subarsono (2011: 90-92) berpandangan bahwa implementasi kebijakan dipengaruhi oleh empat variabel, yaitu : Komunikasi, yaitu keberhasilan implementasi kebijakan mensyaratkan agar implementor mengetahui apa yang harus dilakukan, dimana yang menjadi tujuan dan sasaran kebijakan harus ditransmisikan kepada kelompok sasaran (target group), sehingga akan mengurangi distorsi implementasi. Secara jelas dan konsisten, tetapi apabila implementor kekurangan sumberdaya untuk melaksanakan, maka implementasi tidak akan berjalan efektif. Sumber daya tersebut dapat berwujud sumber daya manusia, misalnya kompetensi implementor dan sumber daya
finansial.Disposisi, adalah watak dan karakteristik yang dimiliki oleh implementor, seperti komitmen, kejujuran, sifat demokratis. Apabila implementor memiliki disposisi yang baik, Moleong, Lexy (2007) maka implementor tersebut dapat menjalankan kebijakan dengan baik seperti apa yang diinginkan oleh pembuat kebijakan. Ketika implementor memiliki sikap atau perspektif yang berbeda dengan pembuat kebijakan, maka proses implementasi kebijakan juga menjadi tidak efektif. Di pasar tradisional terdapat banyak jenis komodiatas yang diperjual-belikan biasanya adalah barang-barang kebutuhan rumah tangga seperti sayuran, sembako, pakaian, dan barang kebutuhan sehari-hari lainya. Perpres No. 112 Tahun 2007 yang mengatur tentang pasar modern dan pasar tradisional. Akan tetapi, pada kenyataannya peraturan tersebut tidak di implementasikan dengan baik.

Implementasi juga merupakan proses untuk memastikan terlaksananya suatu kebijakan dan tercapainya kebijakan itu (Surandari, 
2010:7). Jadi implementasi membahas tentang bagaimana penerapan suatu kebijakan dalam pelaksanaannya dalam kehidupan sehari-hari dan implementasi juga bisa disebut sebagai outputs, yaitu melihat apakah aktifitas dalam rangka mencapai tujuan program telah sesuai dengan arahan implementasi sebelumnya atau bahkan mengalami penyimpanganpenyimpangan.

\section{Van Meter dan Van Horn}

dalam Winarno

membatasi implementasi kebijakan sebagai tindakan-tindakan yang dilakukan oleh individu-individu (atau kelompok-kelompok) pemerintah maupun swasta yang diarahkan untuk mencapai tujuantujuan yang telah ditetapkan dalam keputusan-keputusan kebijakan sebelumnya.Peraturan Presiden Republik Indonesia Nomor 112 Tahun 2007 Tentang Penataan dan Pembinaan Pasar Tradisonal, pada bagian pertama penataan pasar Tradisonal pasal 2 yaitu Pasar Tradisonal wajib mengacu pada Rencana Tata Ruang Wilayah. Pendirian Pasar Tradisional.
Penyediaan areal parkir dapat dilakukan berdasarkan kerjasama antara pengelola pasar Tradisional dengan pihak lainnya.

Pengertian pasar tidak harus dikaitkan dengan suatu tempat yang dinamakan pasar dalam pengertian sehari-hari."Pasar mencakup keseluruhan permintaan dan penawaran, serta seluruh kontak antara penjual dan pembeli untuk mempertukarkan barang dan jasa" (Rita Hanafie, 2010:176). Dalam kamus Ekonomi \& Bisnis "Pasar merupakan tempat terjadinya penawaran dan permintaan antara penjual yang ingin menukarkan barang-barangnya dengan uang dan pembeli yang ini menukarkan uangnya dengan barang atau jasa" Waluyo Hadi \& Dini Hastuti, (2011: 364-365). Pengertian dari toko modern ini diatur dalam Pasal 1 angka 5 Peraturan Presiden Nomor 112 Tahun 2007 tentang Penataan dan Pembinaan Pasar Tradisional, Pusat Perbelanjaan Dan Toko Modern. 


\section{METODE PENELITIAN}

Penelitian akan dilaksanakan dua bulan setelah ada izin penelitian. Alasan peneliti memilih penelitian ini karena peneliti melihat adanya masalah pada penataan pasar Tradisional melihat kondisi pasar yang tidak dikelolah dengan baik, Mengacu pada judul skripsi ini, maka lokasi penelitian ini adalah Pasar Tradisional Di Kecamatan Somba Opu Kabupaten Gowa, telah berhadapan dengan masalah penataan yang kurang profesional dan ketidaknyamanan bagi para pengunjung, kondisi pasar yang sangat memprihatinkan.Jenis penelitian ini adalah penelitian deskriptif kualitatif. Tipe penelitian yang digunakan adalah fenomenologi.

Sesuai dengan tipe dalam penelitian ini adalah fenomenologi maka Pemilihan informan yang akan diwawancarai dipilih berdasarkan pada tujuan penelitian dan pertimbangan tertentu, alasan dipilihnya beberapa informan dari Dinas Perindustrian dan Perdagangan (Disperindag) Kabupaten Gowa sesuai dengan tugas tugas pokoknya beserta masyarakat yang memiliki kios itu didasari dengan pertimbangan yang akan didapatkan informasi yang akurat dan detail yang mudah di mengerti, meliputi : Kepala Disperindag 1 orang, Kasub. Perencanaan \& Pelaporan Disperindag 1 orang, Seksi Pengembangan Pasar \& Promosi Disperindag 1 orang, Bidang Perdagangan Disperindag 1 orang, Kepala Pasar Kec. Somba Opu 1 orang, Masyarakat Yang Memiliki Kios 4 orang.

Dalam proses penelitian ini, penulis menggunakan teknik pengumpulan data berupa Wawancaramerupakan teknik pengumpulan data yang dilakukan dengan cara tanya jawab, Observasi merupakan suatu teknik pengumpulan data yang dilakukan melalui pengamatan secara langsung, dan Dokumentasi, Teknik analisa data meliputi :Reduksi Data, Sajian data, Penarikan Kesimpulan. Keabsahan data meliputi : Triangulasi Sumber.Triangulasi Teknik.Triangulasi Waktu. 
HASIL DAN PEMBAHASAN

Kecamatan Somba Opu adalah salah satu Kecamatan yang ada di Kabupaten Gowa, Kecamatan Somba Opu merupakan Kecamatan Ibukota yang memiliki 14 Kelurahan dan 28 Lingkungan.Kecamatan Somba Opu merupakan satu kecamatan yang berada di Kabupaten Gowa yang letaknya berada di Ibukota Kabupaten dan berbatasan langsung denganIbukota Provinsi Sulawesi Selatan. Adapun luas kecamatan Somba Opu adalah $28,09 \mathrm{Km} 2$ atau $2.809 \mathrm{Ha}$.

Kecamatan Somba Opu berada pada wilayah dengan ketinggian 25 meter di atas permukaan laut. Sebagian besar wilayah terletak pada dataran rendah dengan koordinat geografis berada pada 5 derajat 12'5" LS dan 119 derajat 27'15" BT. Batas alam dengan kecamatan Palangga adalah sungai Je'neberang yaitu sungai dengan panjang $90 \mathrm{Km}$ dan luas daerah aliran sungai $881 \mathrm{Km} 2$.

Peraturan Presiden Nomor

112 Tahun 2007 tentang Penataan Pasar Tradisional yaitu di bab 2 pasal 2 nomor 1 meliputi Lokasi Pasar
Tradisonal wajib mengacu pada Rencana Tata Ruang Wilayah/Kota, dan rencana detail Tata Ruang Kabupaten/Kota, termasuk peraturan zonasinya. Pasar tradisional merupakan suatu bentuk kegiatan pendistribusian barang dari produsen kepada konsumen. Kegiatan ini terbentuk karena adanya permintaan masyarakat akan kebutuhan barang. Dalam penyusunan arahan penataan pasar tradisional perlu dilakukan pertimbangan pemenuhan standar penataan fisiknya. Untuk menentukan penataan seperti apa yang perlu diterapkan, diperlukan kriteria-kriteria yang dapat digunakan untuk menilai kondisi pasar tradisional yang ada Lokasi pendirian Pasar Tradisonal wajib mengacu pada Rencana Tata Ruang Wilayah.

Dalam lokasi pendirian pasar tradisional implementasi itu dapat dimaksudkan sebagai suatu aktivitas yang bertalian dengan penyelesaian suatu pekerjaan dengan penggunaan sarana (alat) untuk memperoleh hasil. Apabila pengertian implementasi di atas dirangkaikan dengan kebijakan publik. 
PermasalahankebijakanBerda sarkan Rencana Tata Ruang Wilayah, penataan lokasi pasar akan mengadopsi konsep yang telah diterapkan dalam penataan di Kabupaten Gowa terkhusus pasar yang berada di Kecamatan Somba Opu, yaitu sebagai bagian dari pelayanan pusat sekunder yang berfungsi untuk menahan pergerakan penduduk ke pusat kota (sebagai buffer), Bentuk pasar ini bisa berupa pasar modern (shopping mall),ataupun pasar tradisional namun dengan penataan dan pengaturan yang ketat.

$$
\text { Pendirian pasar }
$$

tradisional,lokasi yang strategis sesuai dengan segmen pasarnya. Pusat perdagangan dengan segmen pasar yang sama tidak boleh terlalu berdekatan, dalam lokasi pendirian pasar tradisional yang strategis Pusat perdagangan dengan segmen pasar yang sama tidak boleh terlalu berdekatan, penyediaan sarana perdagangan sangat perlu agar suatu perekonomian dalam pasar tradisional ini bisa berkembang dengan baik.
Dalam lokasi pendirian pasar tradisional dengan menentukan potensi suatu area untuk dijadikansuatu area perdagangan maka diperlukan informasi mengenai populasi, dalam hal ini faktor pemilihan pusat perdagangan seperti lalu lintas pejalan kaki, lalu lintas kendaraan, fasilitas parkir, transportasi umum, komposisi toko dalam area yang berdekatan, letak bangunan semua ini berkaitan dengan tata kelola dan ketentua pemakaian ruang.

Penentuan lokasi pasar tradisional Melalui kajian ini dibatasi pada hal hal utama diantaranya jumlah penduduk sebagai dasar permintaan, Ketersediaan Lokasi, aksesbilitas lingkungan seperti jalan maupun kedekatan dengan pemukiman, dukungan politik, dan jarak dengan pasar terdekat. Penentuan lokasi pasar tradisional akan dilakukan melalui tahapan seperti mengidentifikasi cikal bakal pasar tradisional maka dari itu keberadaan pasar dalam lokasi pembangunan disesuaikan dengan keperluannya. 


\begin{abstract}
Lokasi pasar akan mengadopsi konsep yang telah diterapkan dalam penataan di Kabupaten Gowa terkhusus pasar yang berada di Kecamatan Somba Opu belum optimal, lokasi pendirian pasar tradisional yang strategis Pusat perdagangan dengan segmen pasar yang sama tidak boleh terlalu berdekatan, penyediaan sarana perdagangan sangat perlu, Jumlah penduduk, lokasi pasar, jumlah pedagang, luas pasar dan pengelola, sarana dan prasarana penunjang diperlukan.
\end{abstract}

\section{Peraturan Presiden Nomor} 112 Tahun 2007 tentang Penataan Pasar Tradisional yaitu di bab 2 pasal 2 nomor 2 Pendirian Pasar Tradisional wajib memenuhi ketentuan Memperhitungkan kondisi sosial ekonomi masyarakat dan keberadaan pasar Tradisional, pusat perbelajaan dan Toko Modern serta usaha kecil, termasuk koperasi yang ada di wilayah yang bersangkutan. Menyediakan area parker, dan Menyediakan fasilitas yang menjamin pasar Tradisonal yang bersih, sehat, aman, tertib dan ruang publik yang aman.
Pendirian pasar tradisional untuk mewujudkan visi menjadi pusat belanja hendaknya terdapat beberapa kebijakan dan program kegiatan. Pendirian pasar tradisional dilakukan dengan melakukan revitalisasi sarana dan prasarana fisik, peningkatan kualitas barang dagangan dan pemberdayaan pelaku pasar, pendirian pasar tradisional dilakukan dengan melakukan revitalisasi sarana dan prasarana fisik, peningkatan kualitas barang dagangan dan pemberdayaan pelaku pasar, Revitalisasi keadaan fisik pasar tradisional dan pembangunan sarana dan prasarana penunjang, dengan membatasi perijinan pembangunan pusat-pusat perbelanjaan modern.

Pendirian pasar tradisional mempunyai Wujud revitalisasi dan pembangunan sarana dan prasarana adalah pembangunan fisik pasar tradisional, belum ada standar yang pasti pasar mana yang akan dibangun, lebih lanjut berkaitan dengan zona pasar tradisional, dalam menentukan pendirian pasar mana yang akan dibangun fisiknya kembali 
tetapi melihat dari dimana lokasinya dan pembagunan fisik pasar tersebut.

Dalam menentukan pendirian pasar yang bentuk bangunannya relatif sederhana, dengan suasana yang relatif kurang menyenangkan ruang tempat usaha sempit, sarana parkir yang kurang memadai, kurang menjaga kebersihan pasar, dan penerangan yang kurang baik, dalam menentukan pendirian pasar tradisional, pusat pembelanjaan dan pasar modern telah diatur dalam pilpres No. 12 Tahun 2007 dimana pendiriannya harus mengacu pada rencana tata ruang kabupaten/kota dan rencana detail tata ruang kabupaten/kota.

Pendirian pasar tradisional Penentuan tata ruang wilayah yang memberikan lokasi yang tepat untuk aktivitas usaha pada gilirannya akan memberikan potensi lebih besar untuk menarik investasi, namun demikian, tata ruang wilayah juga harus memperhatikan pula kondisi ekonomi, budaya maupun sosial masyarakat, pendirian pasar perlunya fasilitas, perlengkapan, dan staf yang diperlukan untuk melaksanakan rencana, Pengelompokan dan pembagian kerja menjadi struktur organisasi yang teratur.

Menunjangnya penataan pasar tradisional diperlukan untuk melaksanakan rencana pola mengembangkan lokasi pasar tradisional yang sudah ada, melalui pertimbangan Jumlah penduduk, lokasi pasar, jumlah pedagang, luas pasar dan pengelola, sarana dan prasarana penunjang sangat diperlukan agar dapat berjalan dengan optimal.

Pendirian pasar tradisional dilakukan dengan melakukan revitalisasi sarana dan prasarana fisik, tata ruang wilayah juga harus memperhatikan pula kondisi ekonomi, budaya maupun sosial masyarakat setempat agar inventasi tidak hanya memberikan keuntungan semata bagi bagi pemerintah daerah tetapi juga masyarakatnya secara keseluruhan belum optimal.

Peraturan Presiden Nomor 112 Tahun 2007 tentang Penataan Pasar Tradisional yaitu di bab 2 pasal 2 nomor 3 penyediaan areal parker. Permasalahan parkir sangat penting untuk dikaji lebih mendalam, karena hampir semua aktivitas kegiatan 
diruang terbuka memerlukan sarana tempat parkir. Ruang parkir yang dibutuhkan harus tersedia secara memadai. Sebab dengan semakin besar volume lalulitas yang beraktivitas baik yang meninggalkan atau menuju pusat kegiatan, maka semakin besar pula kebutuhan ruang parkir. Untuk mengkaji permasalahan tersebut, maka fokus penelitian ini adalah mengidentifikasi perilaku lalu lintas terutama kendaraan yang berkunjung ke Pasar Sentral Sungguminasa dan Pasar Maminasata dan memerlukan parkir. Selanjutnya penganalisis langkah pemecahan masalah parkir dan menentukan konsep penataan ruang parkir yang aman dan nyaman.

Dihadapkan pada masalah penyediaan dan pelayanan parkir. Salah satu diantaranya adalah kesulitan untuk pengadaan fasilitas parkir yang sesuai dengan tingkat permintaan atau kebutuhan para pengunjung pasar, dihadapkan pada masalah penyediaan dan pelayanan parkir yang telah ada selama ini di pasar tradisional belum atau tidak efektif. Hal ini disebabkan karena kurangnya alokasi lahan parkir sehingga kebutuhan pengunjung.

$$
\text { Belum optimalnya }
$$

permasalahan parkir sangat penting untuk dikaji lebih mendalam, karena hampir semua aktivitas kegiatan diruang terbuka memerlukan sarana tempat parkir, permasalahan parkir sangat penting, karena hampir semua aktivitas kegiatan diruang terbuka memerlukan sarana tempat parkir. Ruang parkir yang dibutuhkan harus tersedia secara memadai, baik kaitannya dengan jarak tempat parkir dengan bangunan harus ditata dengan baik.

Salah satu diantaranya adalah belum optimalnya penyediaan areal parker dan akan berakibat kesulitan untuk pengadaan fasilitas parkir, bangunan atau tempat kegiatan diusahakan tidak terlalu jauh, bila jarak antara tempat parkir dengan pusat kegiatan cukup jauh, maka diperlukan sirkulasi yang jelas dan terarah menuju area parkir, semakin besar pula kebutuhan ruang parkir, bila tidak cukup kendaraan tersebut akan mengambil parkir ditepi jalan diseputar kawasan tersebut, sehingga menyebabkan kesemrawutan. 


\begin{abstract}
Komunikasi kebijakan pengelolaan pasar tradisional merupakan penyampaian informasi kebijakan termasuk program program pelaksana kebijakan dan program dan disampaikan kepada kelompok sasaran kebijakan serta pihak lain yang berkepentingan yaitu para pedagang pasar tradisional.

Pasar tradisional mempunyai daya saing tradisional terhadap pasar modern yang relatif lemah, kondisi fisik yang belum memenuhi standar pasar sehat, kesan kumuh dan kotor yang belum sirna, manajemen belum professional, faktor komunikasi kebijakan pengelolaan pasar tradisional mencakup faktor transmisi, kejelasan, konsistensi, daya saing, pasar sehat, pembinaan dan penataan pasar tradisional.
\end{abstract}

Komunikasi sangat penting dalam penataan pasar tradisional, dalalm hal ini komunikasi eksternal terjadi diantarapejabat pengelola pasar dengan para pedagang pasar tradisional dengan kelancarannya komunisi akan berdampak baik buat pasar itu sendiri.

Keterlibatan pedagang dalam komunikasi ini bertujuan agar mereka juga mengetahui apa yang harus dipersiapkan pedagang yang terdapat di hampir setiap pasarberfungsi sebagai jembatan untuk menyambung informasi dari pedagang kepada pengelola, dalam suatu penataan pasar tradisional itu sendiri komunikasi harus berlangsung setiap rutin sebagaibentuk keteraturan dan konsistensi dalam upaya mengoptimalkan penataan pasar tradisional.

Upaya pengoptimalkan penataan pasar tradisional Komunikasi internal terjadi antar pejabat pengelola pasar yaitu pejabat struktural pada Dinas Disperindag Kabupaten Gowa dengan pejabat unit pelaksana teknis di masingmasing pasar tradisional yang tersebar terkhusus di Kecamatan Somba Opu.

Penataan fisik pasar dan pengelolaan pasar tradisional bertaraf modern Opu menjadi gerbang pertama dalam upaya mengajak masyarakat untuk meningkatkan ekonomi kerakyatan, teknik-teknik komunikasi yang baik, ini juga momentum yang baik bagi pedagang 
dalam mendapatkan informasi, komunikasi merupakan hal yang penting, dengan adanya komunikasi Setiap satu bulan sekali diadakan rapatkoordinasi, dengan ini komunikasi setiap pimpinan dan bawahan itu sendiri sangat berarti agar penataan pasar tradisional di Kecamatan Somba Opu bisa berjalan dengan baik.

Komunikasi eksternal terjadi diantara pejabat pengelola pasar dengan para pedagang pasar tradisional di Kecamatan Somba Opu Kabupaten Gowa, dalam hal ini adanya pertemuan diadakan rapat koordinasi kepala pasar dan pejabat struktural di Dinas Disperindag Kabupaten Gowa.

Sumber daya merupakan
faktor yang menghambat
implementasi kebijakan karena
implementasi kebijakan memerlukan
dukungan sumber daya manusia
maupun sumber anggaran untuk
melaksanakan kebijakan tersebut,
sumber daya merupakan hal sangat
penting untuk menunjang dan
melaksanakan kebijakan, Jumlah
pegawai pada Dinas Perindustrian
dan Perdagangan masih kurang

mencukupi, untuk mengatasinya dengan mengoptimalkan kinerja, sumber daya suatu kompetensi pegawaimereka tidak ditempatkan pada bidang keahlian sesuai dengan latar belakang pendidikan dan keahlian masing-masing.

Sumber daya bisa dikatakan juga dengan sumber daya anggaran, Anggaran atau biaya programprogrampengelolaan dan pengembangan pasar bersumber dari Anggaran Pendapatan dan Belanja Negara (APBN). Anggaran sangatpenting untuk menopang keberhasilan program pengelolaan dan pengembanganpasar tradisional di Kabupaten Gowa, perbaikan terhadap sarana prasarana pasar terhadap fasilitas-fasilitas mikro sepertiperparkiran atau pengantian atap bagi pasar yang memang mengalami kerusakan, sumber daya merupakan kebijakan untuk mengoptimalkan suatu kinerja beberapa tugas yang diemban berkaitan dengan upaya untuk meningkatkan profesionalitas pegawai, sumber daya sangat penting dalam hal ini penataan pasar tradisional perlunya sumber daya 
manusia dan sumber anggaran untuk menentukan kebijakan dalam mengaktifkan apa-apa saja yang harus dilakukan dalam penataan pasar tradisional tersebut.

Untuk mengatasi, upaya yang dilakukan adalah mengoptimalkan kinerja staf dalam menyelesaikan tugas yang diemban, Anggaran atau biaya program-programpengelolaan dan pengembangan pasar bersumber dari Anggaran Pendapatan dan Belanja Negara (APBN), revitalisasi pasar sifatnya adalah perbaikan terhadap sarana prasarana pasar terhadap fasilitas-fasilitas yang memadai.

Pemerintah mewujudkan pasar tradisional yang baik dan optimal, perlu didukung watak dan karakteristik yang dimiliki oleh implementor, seperti komitmen, kejujuran, sifat demokratis. Apabila implementor memiliki disposisi yang baik, maka implementor tersebut dapat menjalankan kebijakan dengan baik seperti apa yang diinginkan oleh pembuat kebijakan. Ketika implementor memiliki sikap atau perspektif yang berbeda dengan pembuat kebijakan, maka proses implementasi kebijakan juga menjadi tidak efektif, pasar tradisional, disposisi berisi standar perabotan dan dimensi manusia yang menunjang keberadaan pasar tradisional sebagai ruang publik yang merupakan suatu sarana dan prasarana, pasar tradisional, disposisi merupakan tujuan mendasar agar tugas-tugas dilaksanakan dengan baik, sarana dan prasarana pasar yang berada di Kecamatan Somba Opu itu, kondisi yang ada adalah terbatasnya sarana dan prasarana, tanpa adanya sarana dan prasarana yang baik, maka akan menjadi hambatan dalam penataan pasar tradisional tersebut, maka dari itu pihak pengelolaan pasar perlu melakukan pembenahan agar dapat dikelola dengan baik.

Pasar tradisional, masalah yang menyangkut tentang pasar tradisional disposisi sangat berpengaruh baik atasan maupun bawahannya itu sendiri, pusat pasar tradisional masih menunjukkan kondisi yang kurang tertata antara lain jumlah pedagang yang semakin meningkat, keterbatasan lahan dan pengelolaan pasar yang buruk kondisi sarana dan prasarana masih 
belum optimal, pasar dengan profesional yang akan tradisionalmasih menunjukkan kondisi yang kurang tertata antara lain jumlah pedagang yang semakin meningkat, perlunya disposisi agar penataan pasar tradisioanl tersebut ada laporan yang jelas dan bisa dipertanggung jawabkan, pasar tradisional harusnya dioptimalkan penataannya tersebut disposisi sangat penting agar suatu kegiatan yang dipertanggung jawabkan bisa lebih optimal dalam mengelola pasar tradisional tersebut.

Suatu disposisi tentunya memberikan kemungkinan mendasar bagi jenis-jenis kegiatan, dalam hal ini penataan pasar tradisional di Kecamatan Somba Opu, harusnya dioptimalkan penataannya bahwa sarana dan prasarana pasar tradisional di Kecamatan Somba Opu belum memadai, perlunya penataan yang baik akan berdampak baik pula kepada sarana dan prasarana yang mendukung, meningkatnya jumlah penduduk dan aktifitas masyarakat menyebabkan keberadaan pasar juga menjadi penting, oleh karena itu pasar tradisional sangat penting, fasilitas perlu dibenahi, agar dikelola terciptanya suatu pasar yang bersih dan nyaman.

suatu partisipasi masyarakat sangat berperang penting dalam kemajuan pasar tradisional tersebut. Dalam partisipasi masyarakat atau penghuni pasar bisa dikatakan sifat kekeluargaan didalam pasar tradisional tersebut sangat kental, diantara penjual dan pembeli pun terjadi interaksi kekeluargaan saling tawar menawar dan saling menguntungkan di pasar tradisional di Kecamatan Somba Opu dalam partisipasi masyarakat atau penghuni pasar bisa dikatakan sudah baik.

\section{KESIMPULAN}

Berdasarkan hasil penelitian yang telah diuraikan pada bab sebelumnya, maka penulis dapat mengambil kesimpulan bahwa Implemnetasi Peraturan Presiden Nomor 112 Tahun 2007 Tentang Penataan Pasar Tradisional Di Kecamatan Somba Opu Kabupaten Gowa, berada dalam kategori yang baik, meskipun hasilnya belum maksimal. Adapun kesimpulan hasil penelitian dapat diuraikan sebagai 
berikut lokasi Pasar Tradisonal wajib mengacu pada Rencana Tata Ruang Wilayah/Kota, dan rencana detail Tata Ruang Kabupaten/Kota, termasuk peraturan zonasinya

Penataan lokasi pasar akan mengadopsi konsep yang telah diterapkan dalam penataan di Kabupaten Gowa terkhusus pasar yang berada di Kecamatan Somba Opu belum optimal, lokasi pendirian pasar tradisional yang strategis Pusat perdagangan dengan segmen pasar yang sama tidak boleh terlalu berdekatan, 2. Pendirian Pasar Tradisional

Pendirian pasar tradisional dilakukan dengan melakukan revitalisasi sarana dan prasarana fisik, tata ruang wilayah juga harus memperhatikan pula kondisi ekonomi, budaya maupun sosial masyarakat setempat agar inventasi tidak hanya memberikan keuntungan semata bagi bagi pemerintah daerah tetapi juga masyarakatnya secara keseluruhan belum optimal.

Penyediaan Area Parkir Salah satu diantaranya adalah belum optimalnya penyediaan areal parker dan akan berakibat kesulitan untuk pengadaan fasilitas parkir, bangunan atau tempat kegiatan diusahakan tidak terlalu jauh, bila jarak antara tempat parkir dengan pusat kegiatan cukup jauh. Faktor-faktor yang menghambat Implemnetasi Peraturan Presiden Nomor 112 Tahun 2007 Tentang Penataan Pasar Tradisional Di Kecamatan Somba Opu Kabupaten Gowa meliputi : Komunikasi eksternal terjadi diantara pejabat pengelola pasar dengan para pedagang pasar tradisional di Kecamatan Somba Opu Kabupaten Gowa, dalam hal ini adanya pertemuan diadakan rapat koordinasi kepala pasar dan pejabat struktural di Dinas Disperindag Kabupaten Gowa dan Sumber Daya yaitu Untuk mengatasi, upaya yang dilakukan adalah mengoptimalkan kinerja staf dalam menyelesaikan tugas yang diemban, Anggaran atau biaya program-program pengelolaan dan pengembangan pasar bersumber dari Anggaran Pendapatan dan Belanja Negara (APBN), suatu disposisi tentunya memberikan kemungkinan mendasar bagi jenis-jenis kegiatan, dalam hal ini penataan pasar tradisional di Kecamatan Somba 
Opu, harusnya dioptimalkan penataannya bahwa sarana dan prasarana pasar tradisional di Kecamatan Somba Opu belum memadai.

Suatu partisipasi masyarakat sangat berperang penting dalam kemajuan pasar tradisional tersebut. Dalam partisipasi masyarakat atau penghuni pasar bisa dikatakan sifat kekeluargaan didalam pasar tradisional tersebut sangat kental, diantara penjual dan pembeli pun terjadi interaksi kekeluargaan saling tawar menawar dan saling menguntungkan di pasar tradisional di Kecamatan Somba Opu dalam partisipasi masyarakat atau penghuni pasar bisa dikatakan sudah baik.

\section{DAFTAR PUSTAKA}

Djatmiko. 2011. Sistem revitalisasi Pasar diruang lingkup eksternal. Jakarta : PT. Gramedia Pustaka Utama

George C. Edward Edward III, 2011, Implementasi Kebijakan. Jakarta Selatan. Visimedia

Kusumanegara. 2010. Kebijakan. Jakarta: PT. Gramedia Pustaka Utama
Mankiw, N. Gregory, 2006. Pasar Tradisional.Yogyakarta: Liberty

Moleong, Lexy, 2007, Metodologi penelitian Kualitatif, Bandung:PT. Remaja Rosdakarya

Rita, Hanafie. 2010. Dalam kamus Ekonomi \&Bisnis. Jakarta: PT. Gramedia Pustaka Utama

Surandi. 2010. Implementasi kebijakan publik. Jakarta: Erlangga

Wahab. 2004. Implementasi Politik. Jakarta: PT. Gramedia Pustaka Utama

Waluyo, Hadi, Dini, Hastati. 2011 Pasar Modern dan Tradisional.Jakarta : Bumi Aksara.

Winarno, 2002. Implementasi kebijakan.Jakarta: Bumi Aksara.

Peraturan Presiden Republik Indonesia Nomor 112 Tahun 2007 Tentang Penataan dan Pembinaan Pasar Tradisonal, pada bagian pertama penataan pasar Tradisonal.

Peraturan Daerah Kabupaten Gowa nomor 5 Tahun 2009 Tentang Penataan Dan Pembinaan Pedagang Kaki Lima. 